\title{
A BIBLIOGRAPHIC SURVEY OF JEWISH, CHRISTIAN, ISLAMIC, HINDU AND BUDDHIST INCLUSIVISMS
}

\author{
SHAFFARULLAH ABDUL RAHMAN \\ Pusat Penataran Ilmu dan Bahasa, Universiti Malaysia Sabah, Jalan UMS, \\ 88400 Kota Kinabalu, Sabah \\ shaffarullah@gmail.com \\ Dihantar: 1 Okt 2018 / Diterima: 10 Dis 2018
}

\begin{abstract}
Given that the world is religiously diverse, how do home religions negotiate the achievability of salvation for the adherents of foreign religions? This article surveys Jewish, Christian, Islamic, Hindu and Buddhist inclusivisms. This paper distinguishes between theistic inclusivism and nontheistic inclusivism since salvation is understood differently from theistic and non-theistic religions. Theistic inclusivism maintains that all paths run through God, whereas non-theistic inclusivism maintains that the core of salvation is escape from the cycle of rebirth and suffering.
\end{abstract}

Keyword: Inclusivism, Judaism, Christianity, Islam, Hinduism, Buddhism, salvation, theism, non-theism.

\section{INTRODUCTION}

How do different religions negotiate salvation for those who are not members of the same religion? It is standardly maintained that there are three main responses to this question: exclusivism, inclusivism and pluralism ${ }^{1}$. Salvific exclusivism denies that salvation is achievable outside the exclusivist's home religion. Reasons for this denial are typically connected to beliefs about the truth of the 'home' religion and the falsity of 'foreign' religions. Salvific inclusivism recognizes salvation is achievable outside the inclusivist's home religion, but the salvific mechanism of others is solely explainable through inclusivist's home religion. Salvific pluralism maintains that salvation is equally achievable inside everyone's home religion without appealing to salvific requirements or criteria of home religions. In what follows, this paper will focus on salvific inclusivism. 
A survey of the literature on inclusivism reveals that Christian inclusivists have long dominated the discussion on inclusivism ${ }^{2}$. While these views are diverse and critical of one another, there are two general reasons for dissatisfaction with Christian inclusivism: First, Christian theism is not the only type of theism; and second, theism is not the only kind of religious worldview. Although the abundance of materials on Christian inclusivism is understandable - due to the fact that most inclusivists who write in English are Christian - the sheer number of Christian inclusivists in the literature seems to leave the impression that saving non-Christians is their task alone for all religious faiths have an equal stake in the normative question about salvation.

To have a balanced discussion on inclusivism, this article distinguishes between theistic and non-theistic inclusivism. The rationale for the two distinctions is that the achievement of salvation is understood differently from theistic and non-theistic points of view. In theism salvation is achievable with an external help from God whereas in non-theism salvation is largely an Ultimate Goal achievable through self-help. Common in both types of inclusivism, though, is the idea that the inclusivist's home religion can explain the salvific achievement of those from 'foreign' religion. As will be shown later in what follows, the theistic/non-theistic distinctions need further qualifications because within the theistic inclusivism and its non-theistic counterparts the differences are varied.

\section{THEISTIC INCLUSIVISM}

This section deals with theistic inclusivism in Christian, Islamic and Jewish traditions. The common thread running Christian, Islamic and Jewish inclusivisms is the idea that God of inclusivist's home religion can explain the salvific mechanism for the adherents of 'foreign' religions.

\section{Christian inclusivism}

Obviously, there are many variations within Christian inclusivism ${ }^{3}$. In spite of intrareligious differences, they all have an unwavering belief in the salvific 
supremacy of Jesus Christ, and they all explain salvation for the adherents of non-Christian religions by adverting to the salvific efficacy of belief in Jesus Christ. In their view, the religious adherents of non-Christian religions can be saved - and can only be saved - through the grace, mercy and love of Jesus Christ. Because of Jesus Christ's grace, mercy and love are meant for all human beings - and not just for those who are in direct communion with, or proclaim explicit faith in, or are baptised followers of Jesus Christeveryone is included in Jesus Christ's wider scheme of salvation. As Netland succinctly expresses the core principles of Christian inclusivism:

(1) There is a sense in which Jesus Christ is unique, normative, or superior to other religious figures, and in some sense it is through Christ that salvation is made available; (2) God's grace and salvation, which are somehow based upon Jesus Christ, are also available and efficacious through other religions; (3) thus other religions should be regarded positively as part of God's purpose for humankind (2008, p. 68).

Consider, for example, Rahner's thesis of the anonymous Christian. According to Rahner, non-Christians, who have never heard the Gospel of Christ at all or who have never been reached evangelically can achieve salvation because Jesus Christ's salvific grace can be indirectly and unknowingly received. That a devout Jew, Muslim, Hindu or Buddhist is not a Christian is factually correct in a conventional sense. But if one is living a devout Jewish, Muslim, Hindu or Buddhist faith in which Jesus Christ's grace is ever present in one's conscience, then one unknowingly leads a religious life made possible only through the grace of Jesus Christ. Although a Jew, Muslim, Hindu or Buddhist devotee does not have an explicit faith in Jesus Christ - and even though this is what is normally required for one to be a Christian - such a person anonymously possesses implicit faith in Jesus Christ (Rahner, 2008, pp. 553-563). As Rahner's views illustrate, the manner in which Christian inclusivists negotiate the salvific efficacy of the adherents of foreign religions is predominantly Christological: since Jesus Christ is the central figure in the Christian understanding of salvation, explanation of salvation of the adherents of foreign religions falls within the compass of this Christ-centred soteriology. 


\section{Islamic inclusivism}

While it is true that some Muslim scholars do not call themselves 'Muslim inclusivists', many express a view that fits one characterisation of inclusivism: they attempt to explain the salvific efficacy of other religions in terms of Islamic requirements for salvation. Because of the scale of the task, this paper does not try to give a comprehensive account of the full range of views about the prospects for salvation of members of other faiths in Islamic history ${ }^{4}$. A brief survey of the literature indicates that there are two ways in which Muslim scholars tend to negotiate salvation of non-Muslims.

First, Muslim scholars who are inclined to be inclusivistic typically explain the salvific achievement of non-Muslims by appealing to the Qur'anic notion of 'People of the Book' (ahl al-kitab), (see, for example, Sachedina (1986), Aydin (2001 \& 2002), and Rahman (2013)) $)^{5}$. Quoting several passages in the Qur'an to support their views (see, for example, 2:62 and 5:69), Muslim scholars tend to argue along the lines that since the Qur'an explicitly considers Jews, Christians and Sabians to be the 'People of the Book', then their afterlife salvation is divinely sanctioned. Since the traditional notion of the 'People of the Book' mainly concerns people of the Abrahamic faiths, some Muslim scholars-both classical and contemporary-expand the 'People of the Book' to include people of non-Abrahamic faiths such as Buddhism ${ }^{6}$. For example, despite Jews and Christians are explicitly mentioned in the Qur'an as the 'People of the Book', Shah-Kazemi argues that the "boundaries defining this category are flexible and not fixed" (2010, p. 12). Shah-Kazemi's strategy to justify the inclusion of Buddhism in the 'People of the Book' category is to appeal to the Qur'anic revelation that every community has been sent a Messenger, including both mentioned and unmentioned Messengers (see, for example, 4: 164). If this is the case, there is a good reason to believe that Buddha is one of Allah's unmentioned Messengers.

Second, while the 'People of the Book' argument is understandably attractive, it lacks the explanatory rigour to explain the salvific mechanism of non-Muslims. In Islam and the Fate of Others: The Salvation Question, Khalil (2012) ${ }^{7}$ attempts to explain the salvific mechanism of non-Muslims 
by explicating the views of the eminent figures in Islamic intellectual history on the salvific fate of non-Muslims. Khalil's book is an important addition to the literature on Islamic inclusivism because he paints a clear picture of the explanatory framework within which Muslim inclusivists discuss the prospects for salvation of the adherents of other religions. Khalil names four eminent Muslim scholars-al-Ghazali (1058-1111), Ibn al-Arabi (1165-1240), Ibn Taymiyya (1263-1328) and Rashid Rida (1865-1935) he deems to be Islamic inclusivists. He says, "none of [the four figures] qualify as soteriological pluralists, neither are they exclusivists. Instead, all four represent different shades of inclusivism" (2012, p. 20). Each of these authors addresses the question whether salvation is available to those who have not heard Islam's message about the oneness of God and/or to those who have heard this message but who have nevertheless not come to accept Islam.

The four scholars provide elaborate exegeses of the Qur'an in order to defend the claim that salvation is available to followers of other religions. Here, however, this paper will present the main conclusion that they draw. According to Khalil (2012, pp. 26-48), al-Ghazali-in Faysal al-Tafriqa bayn al-Islam was al-Zandaqa ${ }^{8}$ - argues that the salvific prospects of nonMuslims depend on a delicate balance between divine mercy ( $\mathrm{rahma}$ ) and the extent and quality of the exposure of those non-Muslims to the teachings of Islam. Al-Ghazali offers a four-fold categorizations of non-Muslims: (1) those who have not heard any of the true Islamic message and who have died as unbelievers; (2) those who have heard a true representation of Islam but reject it and died as non-Muslims; (3) those who have heard only a false representation of Islam and reject it, and died outside Islam; and (4) those who have sincerely sought the truth about Islam, yet who, despite having a true representation of Islam, died as non-Muslims. According to al-Ghazali, if a non-Muslim satisfies (1), (3) or (4), he or she escapes eternal damnation in hell but a non-Muslim who meets (2) is eternally damned. In contrast to al-Ghazali, Khalil (2012, pp. 54-69) says that Ibn Arabi's brand of inclusivism is more universalistic. Ibn-Arabi's esoteric reading of the Qur'anic notions of Heaven, Hell, Mercy and others informs his inclusivist view that because God's mercy outweighs His wrath, salvation is eventually achieved by all. As Khalil puts it "While [Ibn Arabi] affirms the salvation 
of 'sincere' non-Muslims, because of his belief that every single path we take is not only created by but leads to God - a God of mercy (rahma) and nobility (karam) - he maintains that all of humanity, including the most wicked, will ultimately arrive at bliss" (2012, p. 55). Khalil (2012, pp. 74-102) says that the brand of inclusivism that Ibn Taymiya articulates - in al-Jawah al-sahih li-man baddala din al-Masih' —is 'limited' but ultimately universalist. While Ibn Taymiya affirms that those who heard the Islamic message but refuse to revert to Islam will dwell in Hell; his account of Hell seems to be merely an interim place for punishment (2012, pp. 74-102). Ibn Taymiya reasons that since God's mercifulness is overwhelming, this means that God will eventually free everyone in Hell so that everyone ends up in Heaven. In this respect, Ibn Taymiya's Hell is similar to Ibn Arabi's Hell, which is temporal, as opposed to al-Ghazali's Hell which is eternal.

The last Muslim inclusivist included in Khalil's (2012, pp. 112-131) study is Rida. Rida reconsiders al-Ghazali's categories of non-Muslims and revises them so that salvation is also available to those who are truly unreached. Rida rejects the notion of eternal chastisement in the afterlife in favour of temporal chastisement by reinterpreting the scriptural meaning of "abadan" (forever). On his reading, "forever' is not eternity because eternal punishment is inconsistent with the expansiveness of divine mercy.

Among the many insightful things that Khalil says in his study, there is the following observation:

\begin{abstract}
Although [al-Ghazali, Ibn al-Arabi, Ibn Taymiyya and Rashid Rida] were motivated by diverse historical, sociocultural impulse, belonged to various schools of thought, and espoused dissimilar soteriological doctrines, their discussion of salvation of 'Others' emphasize the same two themes: (1) the superiority of Muhammad's message, which is often tied to the notion of divine justice and the idea that the way God deals with His servants is related to their acceptance or rejection of His final message when its truth has become manifest, and (2) the supremacy of divine mercy (rahma), which is often associated with the notion of divine nobility and the idea that God generously overlooks His right to punish those who may 'deserve' it. (2012, p. 20).
\end{abstract}


As in the case of Christian inclusivism, where teachings specific to the Christian religions - concerning the salvific works of Jesus Christare paramount in explaining salvation for followers of other religions, so, too, in the case of Islamic inclusivism, teachings that are specific to Islam-concerning the relationship between God's mercy and the Islamic message of the Oneness of God-form the core of the explanation of the salvation of non-Muslims. While salvation of non-Muslims may depend on the acceptance or rejection of the teachings of Islam, Muslim inclusivists ultimately ground salvation of adherents of other religions in God's overwhelming mercifulness.

\section{Jewish inclusivism}

Alan Brill's (2010) Judaism and Other Religions is perhaps the most comprehensive account of Jewish perspectives on religious diversity. Brill draws upon Race's three-fold paradigm of exclusivism, inclusivism and pluralism ${ }^{10}$ to explain both differences between Jewish inclusivists and their Christian and Muslim counterparts, and differences between various kinds of Rabbinical inclusivism. Cohn-Sherbok's (1994) Judaism and Other Faiths also draws upon Race's tripartite classification but he explicitly rejects Jewish exclusivism and inclusivism. In particular, Cohn-Sherbok argues for a radical shift in Jewish relations to other religions, which he claims is fully expressed by Jewish pluralism. For the purpose in this paper, only Brill's discussion of Jewish inclusivism will be discussed. ${ }^{11}$

Brill (2010) divides Jewish inclusivism into four main types and then collects views from different periods of rabbinical scholarship according to these types ${ }^{12}$. The first type of Jewish inclusivism draws on a view that Bill calls-'historical mission': the emergence of religions such as Christianity and Islam hasten the spreading of belief in, and knowledge of, a monotheistic God and so brings forward the coming of the messianic age (2010, pp. 64-80). This view is held by Yehudah Halevi (1075-1141), Moses Maimonides (1138-1204), Abarbanel (1437-1508), Yaakov Emden (1697-1776), Samson Raphael Hirsch (1808-1888), Rabbi Yehudah Leib Alter (1847-1905) and Rabbi Abraham Isaac Kook (1865-1935) ${ }^{13}$. Inclusivists of this kind view the fact that Christianity and Islam emerge as 
dominant religious forces in the world as part of the divine plan, beyond our human understanding, that ultimately brings humanity closer to knowledge of God. For example, Rabbi Halevi writes in The Book of Kuzari:

\begin{abstract}
All religions that came after the Torah of Moses are part of the process of bringing humanity closer to essence of Judaism, even though they appear its opposite. The nations serve to introduce and pave the way for the long-awaited messiah. He is the fruit and they, in turn, will all become his fruit when they acknowledge Him. Then all nations will become one tree, recognising the common root they had previously scorned. (As cited in Brill, 2010, p. 65)
\end{abstract}

The second type of Jewish inclusivism draws on "a metaphysical, theocentric hierarchy" which "places the understanding of God found in other faiths on a lower level than found in Judaism" (Brill, 2010, pp. 80-86). Brill tells us that this view is strongly advocated by Rabbi David Kimhi (1160-1235), and Rabbi Yosef Gitikila (1248-1305), and can also be found in certain texts in kabbalahism and hasidicism. According to Brill (2010, pp. 82), Gitikila says that: "all religions partake of the true divinity [but] only Israel can draw the powers of Tetragrammaton while other religions refer to a singular and limited aspect of God's powers [for] Israel has direct access to the highest realms of the inter-divine sefirotic system and the other gods are only lower points of the system".

The third variation of Jewish inclusivism is centred on the divine revelation at Mount Sinai, where the knowledge, morals and law contained in the Sinai revelation was not exclusive to the Jewish people who witnessed the event, but intended for the entire human race (Brill, 2010, pp. 86-92). This Sinai-centred inclusivism was espoused by Rabbi Solomon Aderet (1235-1310), Rabbi Isaac Arama (1420-1494), and Rabbi Eliyahu Soloweyczyk. Although the Sinai event is viewed by some Jewish scholars as the single most important event in the development of Judaism's uniqueness and superiority (see, for example, Polish, 1990, p. 52), Jewish inclusivists of this kind see the Sinai revelation in more inclusivistic terms when they think about the relations between Judaism and other religions. 
The fourth type of Jewish inclusivism includes Rabbi Ovadiah Seforno (1470-1550), Avigdor Kara (c. 15 century) and Yehezel Kaufman (1889-1963), each of whom champions a humanistic, theocentric approach to other religions. This approach is primarily based on the assumption that divine providence is meant for all humanity because we are all descendants of Adam (2010, pp. 92-93).

While Brill's typology is helpful in negotiating the contours of Jewish inclusivism in spite of the intra-religious intricacy, it is not immediately clear what it says about the prospects for salvation of non-Jews ${ }^{14}$. To answer this question, this article turns now to Shatz's (2011, pp. 366-368) masterful summary of the variety of rabbinical positions on the salvation of the adherents of other religions from the medieval period to the Jewish enlightenment period. It is important to note here that Shatz does not explicitly say, for the varieties of Islamic inclusivism that he considers, that these positions are inclusivistic in the way that Khalil does. But the way in which Shatz explains the varieties of rabbinical positions on the prospect for salvation of non-Jews is a good fit with the general pattern of theistic inclusivism: the achievability of the salvation of non-Jews is explained in terms of the rightful place of non-Jews in the world to come, where "the world to come" is evidently a parochial Jewish notion.

The problem that concerns Jewish rabbis the most throughout the history of rabbinical scholarship is this: if the promise of redemption in the world to come by the God of Israel is specifically meant only for the Jewish people, can the followers of other religions earn it? Shatz says that "the simplest explanation of the Talmudic position that embracing Judaism is not necessary for a Gentile's entering the world to come is that God wants to give all people just reward" (2011, p. 367). While Maimonides claimed that "righteous Gentiles have a portion in the world to come" (as cited in Shatz, 2011, p. 366), Shatz highlights the much more radical position, advocated by Rabbi Israel Lifshutz (1782-1860), that "even non-Jews who are not fully righteous earn a portion" (2011, p. 367 original emphasis). Although there was a broad consensus amongst the Rabbis in the medieval period that members of the Christian faith will not be redeemed in the world to come because the Christian doctrine of the divinity of Jesus is a clear violation of 
avodah zarah as stipulated in the Noahide law in the Talmudic era (2011, p. 367), Shatz points out to the dissenting view of Rabbi Menaheim ha-Meiri (1249-1316), who reasoned that one needs only to be ethically righteous - as a member of any religious faith can be-in order to have a full portion in the world to come. There has been a paradigm shift concerning avodah zarah amongst Rabbis in the modern period. The bone of contention amongst the Rabbinical scholars in the medieval period concerned the divinity of Jesus: while many medieval rabbis held that the Christian doctrine of the divinity of Jesus is a clear violation of avodah zarah, many modern rabbis took the view that the Christian idolisation of Jesus does not violate the Noahide law because "mistaken conceptions of God held by Gentiles do not ... bar them from the world to come" (Shatz, 2011, p. 367). In the words of Rabbi Jacob Emden, "[Christians] act for the sake of Heaven, for their goal is to promote Godliness among the nations. [Hence], they will not be denied reward for the benevolent intentions" (as cited in Shatz, 2011, p. 367). This inclusivistic view continued during the Jewish Enlightenment period and found its way into the writings of Moses Mendelssohn (1729-1786). Mendelssohn reasoned that if the Gentiles can be morally righteous through rational reasoning, then that is sufficient to earn them a salvific portion in the world to come even if they do not convert to Judaism. Mendelssohn cited Confucius and Solon as examples of morally righteous non-Jews; it would not make sense to deny these morally righteous men a portion in the world to come simply because they are not members of the Jewish religion. In sum: The achievability of salvation for the adherents of foreign religions is explained, in relation to the Jewish doctrine of the world to come, in terms of the salvific portion that the God of Israel promised to the Jews.

\section{NON-THEISTIC INCLUSIVISM}

If the very idea of the theistic God is an odd concept, or commands a lesser value, or is dismissed as having no bearing on the achievement of salvation in non-theistic religions, how does non-theistic inclusivism explain the achievability of salvation in other religions? This sub-section discusses non-theistic inclusivism in the Hindu and Buddhist traditions. 


\section{Hindu inclusivism}

Formulating a workable non-theistic Hindu inclusivism requires a careful qualification. Internally, Hinduism seems richly pluralistic by nature, because its adherents are free to pursue diverse paths to salvation, some theistic, some non-theistic, some, perhaps, a combination of the two. According to Chadha (2015), the folk Hindu notion of ultimate reality is diverse: it allows monotheism, theism, non-theism, pantheism, and more, as valid understandings of ultimate reality ${ }^{15}$. Although Hindu inclusivism will be presented under the umbrella of non-theistic inclusivism in this subsection, this does not mean to suggest that Hinduism is predominantly nontheistic: the theistic/non-theistic distinction is less clear-cut for Hinduism than it is for other religions. As Lawrence writes: "Although Hinduism includes nontheistic philosophies, the majority of its philosophical and scholarly, as well as popular traditions, can be characterized as theistic, in the sense that one or more deities are conceived as the religious ultimate reality and ultimate concern" (2013, p. 78) ${ }^{16}$. While acknowledging Hinduism's interwoven diversity, this article only focuses on the Vedanta School of Hinduism which proclaims Brahman as the supreme principle of Reality. Other schools in the Hindu tradition-Samkhya, Yoga, Vaisheshika and Mimamsa - attribute less importance to this principle ${ }^{17}$. In Vedanta, salvation is achieved when the true nature of the Self (Atman/Brahman) is realised, whereas, in Samkhya, salvation is achieved when our eternal consciousness (purusa) is detached from the material world (prakrti).

A further word of caution is in order: bear in mind that the Vedanta school of Hinduism is itself very diverse. While all Vedantin philosophers affirm the ultimate reality of Brahman, there is a disagreement about the salvific nature of Brahman: As Lott (1980) observes, Shankara's non-dualism is characteristically non-theistic; Ramanuja's qualified nondualism is panentheistic, and Madhva's dualism is strictly monotheistic ${ }^{18}$. The primary focus of this section will be on the writings of Radhakrishnan (1940, 1957 and 1960), which take up questions about religious diversity in some detail. It will be argued that Radhakrishnan - under the influence of Shankara-advocates an inclusivist view of salvation in our religiously diverse world ${ }^{19}$. 
As a point of entry into Radhakrishnan's non-theistic inclusivism, a preliminary issue raised by D'Costa's (2000) critique of Radhakrishnan's (1940) classification of his own view (1940) should be addressed. Consider the following passage from Radhakrishnan's The Hindu View of Life:

Hinduism insists on our working steadily upwards and improving our knowledge of God. "The worshippers of the Absolute are the highest in rank; second to them are the worshippers of the personal God; then come the worshippers of the incarnations like Rama, Krishna, [the] Buddha; below them are those worship ancestors, deities and sages, and lowest of all are the worshippers of the petty forces and spirits" $(1960$, p. 24$){ }^{20}$

One issue that should be addressed is that D'Costa uses this passage as evidence that Radhakrishnan is a Hindu exclusivist, even though Radhakrishnan claims to be a pluralist about religious diversity.

In The Meeting of Religions and Trinity, D'Costa (2000)—who may be the only figure in the literature who has attempted to situate Radhakrishnan's view on religious diversity within Race's exclusivist-inclusivist-pluralist typology—argues that "Radhakrishnan's Hindu pluralism [is] either a form of modernist exclusivism, or some form of religious Hindu exclusivism. In a curious and interesting fashion, we ... find both!" (p. 53). This article will not probe D'Costa's claim that Radhakrishnan's exclusivism is a product of the Enlightenment modernity - a claim that he also levels against Hick, Knitter and Cohn-Sherbok (D' Costa 2000, pp. 19-47) - because it falls outside the scope of my present concern. However, I do want to discuss his insistence that Radhakrishnan's 'pluralism' is ultimately 'neo-Advaita Vedanta exclusivism'. D'Costa's main argument for this view is diffuse but the gist is arguably as follows. Radhakrishnan claims that his "pluralism" is based on his account of mystical experience, which, he says, plays the same central role in all religions. According to D'Costa, Radhakrishnan's account of mystical experience is actually cast in Advaitin terms: it supposes that 'there is no "self", but only Brahman' (2000, p. 64). D'Costa explains: 
Given that the core mystical experience is one of Advaitin non-dual identity, one can see how Radhakrishnan is forced in practice to grade the different religions and their experiences in so much as they conform and differ with regard to this ultimate and definitive standard ... [H]e fundamentally prioritizes some, rather than other, experiences. In so doing, he prioritizes and gives particular status to certain forms of Hinduism... Such a grading exercise finally displays Radhakrishnan's Advaitin metaphysics clearly. Advaita comes first. "Theism" ranks second, especially the demythologized forms which are not related to any historical and particular revelation. The latter, incarnational-based forms of theism, represent the third nearest to the truth. This hierarchy of truths is inevitable ... but it certainly runs against Radhakrishnan's avowed "equalism” (2000, p. 64). ${ }^{21}$

Since this article claims that Radhakrishnan is a Hindu inclusivist, these claims that D'Costa makes will be contested.

Granted that D'Costa's point that it is untenable for Radhakrishnan to claim that his pluralism is both a 'positionless' position and a natural result of Hinduism (2000, pp. 58-59) - an inconsistent position which D’Costa thinks typical of pluralists - but merely because Radhakrishnan explains the underlying experience of mysticism in Advaitin terms, it does not follow that he is a Hindu exclusivist. If we reframe Radhakrishnan's 'pluralism' as the way in which he negotiates the achievement of salvation for the followers of other religions, then it is clear that Radhakrishnan does not completely dismiss the salvific efficacy of other religions. Granted that Radhakrishnan does not take salvation achieved by the members in other religions as ultimately final in Advaitin terms, I do not think that this makes him a soteriological exclusivist. The reason for this is simple: Radhakrishnan does not deny that the followers of other religions can achieve salvation inside their 'home' religions whereas soteriological exclusivists explicitly deny this.

This brings us to the second issue concerning Radhakrishnan's classification of his own view. Clearly, given the manner in which Radhakrishnan differentiates his position from 'exclusivism' and 'inclusivism', he thinks that pluralism has always been Hinduism's default position (1960, pp. 343-347). It is outside the scope of the argument in this sub-section to contest this claim but here this article wants to advance 
one reason why Radhakrishnan's 'Hindu pluralism' is, perhaps, better understood as Hindu inclusivism.

If the passage quoted above indicates Radhakrishnan's pluralistic thinking about religious diversity, then Radhakrishnan's 'pluralism' cannot be pluralistic. Under Radhakrishnan's account, our religiously diverse world is teeming with different 'home' ultimates. But how does he order them? A true pluralist would make a horizontal arrangement of salvific relationships between adherents of different religions and their ultimates, thereby signifying that they are more or less on par with one another. But the problem with Radhakrishnan's pluralistic claim is that he hierarchically ranks the salvific relationships between the 'worshippers' and the ultimates of different religions. This hierarchy implies that the relationship between the 'worshippers' and their respective ultimates have different statuses: some are ranked higher than others. Since Radhakrishnan elevates the Absolutethe realisation of the true Self-above the rest, it follows that he is not a pluralist. Saying that Radhakrishnan is not a pluralist by no means makes him an exclusivist; while relationship with a personal God is inferior to realisation of the true Self, the relationship between worshippers and their personal God is nevertheless salvific (even if, as Radhakrishnan implies in the passage quoted above, it is not ultimately final).

We can now state the explanatory framework of non-theistic Hindu inclusivism with respect to salvation in the following way: While there is salvation outside the inclusivist's home religion, all other paths to salvation are hierarchically dependent upon rebirth. Salvific ends outside Hinduism are possible — and even achievable — but what counts as 'salvific' in other religions may be regarded as an unequal status if the true Self is not realised. While a good Christian or Muslim may secure a piece of real estate in a heavenly realm of existence, that place is merely temporary. In order to finally achieve Moksha, good Christians and Muslims must be reborn into the Hindu religion through a process that may involve many lifetimes. Because they have already achieved a respectable level of spiritual achievement in their previous lives as Christians or Muslims, the newly minted Hindus are primed for the attainment of real salvation, i.e. liberation from samsara. 


\section{Buddhist inclusivism}

It is customary to begin the discussion of Buddhist inclusivism with words attributed to the Buddha ${ }^{22}$. Consider the following passage in Sutta Nipata, which some claim is indicative of the Buddha's inclusivism:

"I do not say, Nanda," said the Blessed one, "that ascetics and brahmins are shrouded in birth and death. Whoever has abandoned here [attachment to] what is seen, heard or sensed, and has abandoned [attachment to] all rules and rituals, and has abandoned [attachment to all] diverse forms, fully understanding craving, without taints, them indeed I call 'stream-crossers" (as cited in Vélez de Cea, 2013, p. 83).

The stream simile in this context symbolises samsara while 'stream crossers' denotes those who are liberated from samsaric existence. This particular passage seems to support strongly the view that the Buddha held that liberation from samsara is not exclusively dependent upon his teachings ${ }^{23}$.

On the other hand, Jayatilleke cautions us not to rush to the conclusion that the Buddha regards all religions as equal: "This assertion of the possibility of salvation or spiritual growth outside Buddhism does not mean Buddhism values all religions alike and considers them equally true" (2013, p. 99). Makransky seems to argue in a similar vein:

Different kinds of spiritual practice lead to different spiritual results, and many of these results fall short of complete liberation from suffering, nirvānna. This is the position taken by Śākyamuni Buddha, whose critical perspective of the practices of other religious systems appears in the Pâli suttas. According to the traditional biographies, if Siddhārtha had been satisfied with another soteriological options of his time, he would not have sought a fuller enlightenment. Indeed, although invited by two of his religious teachers to assume the leadership of their communities, he realised that their systems did not lead all the way to nirvānna, fullest liberation. He felt compelled to go further in his own realisation than any of his teachers so as to rediscover and reintroduce the way revealed by past Buddhas... $[\mathrm{O}]$ ther religious figures of his time mistook lesser spiritual results 
as final, unaware that they had not eliminated all obstacles to deepest liberation from suffering... Śākyamuni taught from a moral imperative to reveal a more precisely targeted mode of practice that could eliminate the subtlest obstacles to liberation (2008, p. 47). ${ }^{24}$

Jayatilleke's and Makransky's arguments seem reasonable because if other religions promote suffering, then it cannot follow that those religions are salvific. Surely, the Buddha did not encounter the Abrahamic religions in his lifetime, but if Judaism, Christianity and Islam 'reinforce' the root cause of suffering, then it can be argued that those religions cannot be soteriologically effective in eliminating suffering. At best, it is controversial whether the Buddha is an exclusivist or non-exclusivist.

To engage debate about whether there is salvation outside Buddhism, this article turns to Vélez de Cea's (2013) The Buddha and Religious Diversity. Vélez de Cea's book is, perhaps, the most detailed study of the historical Buddha's position on religious diversity in the literature.

According to Vélez de Cea, if we understand the historical Buddha's view about what is most important in his own teaching, and in the teaching of other religious traditions - whether it is "God, ultimate reality, salvation, liberation, the fulfilment of the spiritual path, the highest truth, supreme goodness, holiness and so on" (2013, p 15) - the Buddha of the Pãli Nikãyãs - as opposed to what he calls the Buddha of Theravada Buddhism or the Buddha, as the later Buddhists represent him to be-is neither exclusivist nor inclusivist nor pluralist. Rather, the historical Buddha espouses a 'pluralistic-inclusivist view with a plua alistic attitude' - a characterisation which he claims is more accurate than any one of the standard 'exclusivist''inclusivist'-'pluralist' classifications prevalent in the literature. The Buddha is not an exclusivist because the Buddha does not say that liberation from samsara is only achievable through his teaching (2013, pp. 45-77) nor is the Buddha an inclusivist (2013, pp. 81-122). Inclusivism, under Vélez de Cea's account, says that there are multiple instances of salvific ends outside the inclusivist's home religion that are not uniquely different from the salvific ends of the inclusivist's home religion. However, Vélez de Cea claims that the Buddha is open to the possibility that there are salvific instances which are not found in his teachings. Yet, the Buddha's theoretical 
openness does not mean that the Buddha is a pluralist (2013, pp. 178-183). For Vélez de Cea, pluralists are those who are not troubled by differences in doctrinal claims because they accept multiple ultimate ends (see, for example, Heim, 2001). But the Buddha's openness to similar or different instances of ultimate end is limited to those foreign religions that do not contradict his doctrines. Hence, Vélez de Cea contends that the historical Buddha is at best a pluralistic-inclusivist in the sense that he is open to the "new representation of Dharma" found in other traditions unknown to him but this openness to what other traditions consider most important thing is constrained by the "non-negotiable" doctrines in his own teachings.

Although Vélez de Cea reformulates the standard tripartite classification so that the Buddha is not precisely an inclusivist, this does not defeat my attempt to present the Buddha as a non-theistic inclusivist. The manner in which Vélez de Cea uses the term "pluralistic-inclusivism" privileges the Buddhist worldview (e.g. suffering, cause of suffering, nirvana, etc.). As Vélez de Cea is keen to repeat throughout his book (2013, p.180), "The Buddha's nonnegotiable doctrinal claims are the consequence of insight into specific conditionality of suffering; the nature of suffering, its cause, its cessation, and the way leading to its cessation." Despite Vélez de Cea's insistence that the truth of reality which the Buddha discovered from his enlightenment does not depend on "Buddhas, Buddhism and the Buddhist". Buddhist inclusivism must adhere to the non-negotiability of his doctrines in such a way that the salvific efficacy of other religions is to be evaluated from these specific tenets. Since the historical Buddha, under Vélez de Cea's own account of pluralistic-inclusivism, does not completely write off salvific instances in other traditions so long as they conform to the central tenets of the Buddha's own teachings about salvific truth, it seems to follow that salvation is theoretically achievable in other religions. This fact alone is sufficient to establish the Buddha as an inclusivist.

How about other contemporary attempts to present Buddhist inclusivism? Given Buddhism's rich intrareligious diversity, presenting a comprehensive account of Buddhist inclusivism falls outside the scope of this article ${ }^{25}$. Instead, this sub-section focuses on two contemporary Buddhist inclusivists, the Dalai Lama and Masao Abe, ${ }^{26}$ who attempt to explain the 
salvific figure of Christianity from Buddhist points of view. Then, Kristin Kiblinger's more elaborate account of Buddhism inclusivism will be the topic of discussion.

Just as the Buddha's view of religious diversity privileges his teaching, contemporary Buddhists also privilege Buddhist worldviews in explaining the mechanism for the salvific efficacy of other religions. For example, although the Dalai Lama clearly says that the major differences between Christianity and Buddhism concern questions about God and creation (1996, pp. 55), he assesses the salvific status of Jesus Christ in Buddhist terms. Consider: "For me, as a Buddhist, my attitude toward Jesus Christ is that he was either a fully enlightened being or a bodhisattva of a very high spiritual realisation" (Dalai Lama, 1996, pp. 83) ${ }^{27}$. So, under the Dalai Lama's account, Jesus Christ is either an arahant or a bodhisattva. If Jesus Christ is the latter, the Christian notion that Jesus Christ is the Son of God, whose mission is to provide a vehicle for personal salvation for the human race, is rejected; he is not the Son of God, but rather a being who, out of compassion, defers his own full liberation in order to help other people to achieve liberation from suffering ${ }^{28}$.

Masao Abe has written the bulk of his interfaith works on BuddhistChristian dialogue ${ }^{29}$. Here, Abe's interpretation of the traditional Christian notion of God, which he recasts in terms of the Mahayana doctrine of emptiness $^{30}$, will be the focus of this sub-section. Abe claims that he is particularly impressed by one passage in the Epistle of Philippians because it strikes him as a description of the kenotic God:

This doctrine of Christ's kenosis should not be understood to mean that Christ was originally the Son of God and then emptied himself and became identical with humans. Such a view in the temporal order, or the sequential order, is nothing but a conceptual and objectified understanding of the issue, not an experiential and religious understanding. Instead, we should understand the doctrine of Christ's kenosis to mean that Christ as the Son of God is essentially and fundamentally self-emptying or self-negating — because of this fundamental nature, the Son of God is Christ - that is, the Messiah. It is not that the Son of God became a person through the process of his self-emptying, but that fundamentally he is the true person 
and the true God at one and the same time in his dynamic work and activity of self-emptying. (1995a, p. 33 original emphasis) $)^{31}$

Although Abe does seem to acknowledge the orthodox Christian view that Jesus is fully God and fully man at the same time, he refashions it in a way that is alien to the traditional understanding of Jesus. Abe, like the Dalai Lama, seems to view the Christian God as a person who has awakened to Emptiness. But, in contrast with the Dalai Lama's account of Jesus as Bodhisattva, it is not entirely clear how the hypothesis of a kenotic God provides a salvific mechanism for non-Buddhists.

A contemporary Buddhist inclusivist Kristin Kiblinger presents a clearer picture of how salvation works for non-Buddhist. In her book, Buddhist Inclusivism: Buddhist Attitudes towards Religious Others, Kiblinger (2005) champions a form of Buddhist inclusivism which utilises the three-vehicle (triyana) theory, adopted from mahayanasutralamkara -a major text of the Yogacara school of philosophy in the Mahayana tradition ${ }^{32}$. Kiblinger prefers this version of Buddhist inclusivism because she claims that it treats the diversity of the distinctive salvific ends of other religions better while preserving the ultimate salvific end of Buddhism (2005, pp. 78-82). Her basic problem with other forms of Buddhist inclusivism (such as the ones propagated by Hanh and Abe) is that they tend either to impose Buddhist terms directly on other religions, or they advocate a single-end approach, akin to Rahner's anonymous Christianity. Kiblinger argues that a more tenable form of Buddhist inclusivism must recognize the distinctively different ends of the various religions. As Kiblinger explains:

For the case in which the other's end are judged distinct and true or valuable, we must be careful not to assign direct or present salvific value to them, but only indirect contributory value. This is because ascribing direct value would, at bottom, be imposing our home ends onto the other's systems by implying that, as the alien practices, he progresses towards our home end rather than towards his distinct aim. But just because we should not say that the other aim at our liberation does not mean that we have to say that the other cannot achieve our liberation. We may assert that our salvation is available to other eventually, just not currently, or we could take an agnostic stance about the detailed workings of final liberation... Acknowledging real 
alternative ends could mean that a variety of ultimate fulfilments may be achieved, but the ontological facts would determine how those fulfilments are ordered and which is truly ultimate (2005, pp. 80-81).

In this passage, Kiblinger attempts to explain the salvific efficacy of other religions as charitably as possible but she stops short of saying that the salvific end in Buddhism is superior. But there are other passages in which Kiblinger goes much further:

One feature of the Buddhist system that fits nicely with the attributions of indirect value for alien systems is belief in rebirth. The Buddhist notion of rebirth will do the trick of putting off to the future the possibility of achieving liberation ... Moreover, a virtuous non-Buddhist way of life may lead to a rebirth more conducive to the Buddhist way of life, epitomizing indirect contributory value (2005, p. 86).

Although Kiblinger tries to assign "indirect value" to the salvation of non-Buddhists, her version of Buddhist inclusivism adopts a salvific strategy which is similar to that of Hindu inclusivism, wherein the salvific relationships that non-Hindus have inside their home religions are considered to be preparatory for eventual rebirth into the Hindu faith, which can then lead them to the final liberation. In similar fashion, good non-Buddhists can be reborn into the Buddhist faith in the future, allowing them to pursue a path conducive to liberation.

In spite of the similarity here, there are grounds for caution. The ways in which Hindu and Buddhist inclusivists negotiate the achievability of salvation of those in foreign religions by appeal to the doctrine of rebirth differ in two respects. First, according to Hinduism, religious conversion is an alien concept because one cannot simply convert to Hinduism to achieve salvation; rather, one needs to be born into Hinduism to know the doctrine and pursue its path towards salvation ${ }^{33}$. To the contrary, while the notion of rebirth is equally paramount in the Buddhist worldview, one can convert to Buddhism in order to fully commit oneself to the Buddhist path. Second, the Hindu and the Buddhist doctrines of rebirth are not philosophically alike. Hinduism says that when we die, the true Self does not die but is reincarnated in a new body, whereas Buddhism says that there is no true 
Self, but only causally connected selves of momentary stages. In spite of this, good karma in the current life can lead to future stages where false belief in the Self has been overcome.

\section{CONCLUSION}

In a nutshell, Christian, Muslim, Jewish, Hindu and Buddhist inclusivisms all maintain the sense of salvific superiority at the expense of the salvific equality of other religions. When inclusivists consider other religions to be salvific, this consideration is on the inclusivist's terms: other religions do not have an equal salvific value. While Christian, Muslim and Jewish inclusivism are basically theistic in orientation-because the salvation of others needs an external grounding in the God of the inclusivist's home religion-Hindu and Buddhist inclusivists explain the salvific efficacy of foreign religions in a hierarchical sense. In the case of Christian inclusivism, salvation of others is explained by appeal to the salvific work of Jesus Christ. In the case of Islamic inclusivism, salvation of others is explained by appeal to divine mercy. In the case of rabbinical inclusivism, salvation of others is explained by appeal to the idea that non-Jews can deserve a salvific portion in the world to come. In the case of non-theistic inclusivism of the Hindu and Buddhist traditions, salvation is eventually obtained after the root cause of samsaric existence is overcome.

\section{NOTA}

1 It is received wisdom that the threefold typology of exclusivism, inclusivism and pluralism was first popularised in Race's (1983) Christians and Religious Pluralism, and later adopted by many Christians theologians who dealt with the relation between Christianity and other religions in a religiously diverse world. Needless to say, Race's tripartite typology has been vigorously debated in the literature (see, for example, Markham (1993), Knitter (2002), Muck (2002), Schmidt-Leukel (2005), Hedges (2008), D’Costa (2009), Vélez de Cea (2011), and Ward (2012)). In spite of the continuing debate on the exclusivism-inclusivism-pluralism paradigm, Race's tripartite typology remains useful in negotiating the salvation question in a religiously diverse world. While the tripartite typology in its contemporary sense originates from the Christian tradition, Jewish (e.g. Brill (2010)), Muslim (e.g. Khalil (2012) and Atay (2014)) and Buddhist scholars (e.g. Kiblinger (2005), Vélez de Cea (2013)) have recently adopted Race's tripartite system to discuss their own traditions' relations to other religions. 
2 The literature on Christian approaches to religious diversity is enormous. For helpful introductions or anthologies to Christian approaches to religious diversity, see Knitter (1985), Knitter (2002), Markham (2004), Kärkkäìnen (2003), Hedges and Race (2008), Becker and Morali (2010), and Harris, Hedges and Hettiarachchi (2016); for the history of Christian inclusivism from the early and medieval periods of Christianity, see McDermont (2007) and MacDonald (2011).

3 The number of works on Christian inclusivism and Christian universalism are vast and everexpanding. For classic Christian inclusivism, see Moltmann (1993) and Rahner (2008); for pneumatological models of inclusivism or universalism, see Khodr (1971), Pinnock (1992 \& 1996), Dupuis (1997), Yong (2003 \& 2005); for Trinitarian model of inclusivism or universalism, see Pannenberg (1991), D'Costa (2000), Heim (2001), Panikkar (2009), Kärkkäìnen (2013, 2014, 2015 \& 2016), Johnson (2011), and Adiprasetya (2013); for other works on Christian inclusivism or universalism, see D'Costa (1986), Dinoia (1992), Sanders (1992), Strange (2002), Tiessen (2004), O'Collins (2008), Punt (2008), Greggs (2009), Jersak (2009), Kronen and Reitan (2011), Bradley (2012), MacDonald (2012), Cheetham (2013), and Talbott (2014). According to Nah (2012, p. 19), there are also "eschatological evangelization" Christian inclusivists such as Lindbeck, Fackre, Bloesch, Swinburne and Dinoia. For other discussion of the typology of Christian inclusivism, see Hick (2001, pp. 182-188).

4 For the most comprehensive anthology of Islam and religious diversity, see Ridgeon (2012); for the most comprehensive historical overview of Islam's perception of other religions, see, Waardenburg (1999 \& 2003); for a general Qur'anic overview of other religions, see Sachedina (2006) and Kamali (2011). For a useful anthology of Islam and salvation of others, see Khalil (2013).

5 For an exclusivist interpretation of the 'People of the Book', see Sabjan (2009).

6 For a useful overview of the classical and contemporary attempt to justify the inclusion of Buddhists as 'People of the Book', see Yusuf (2010, pp. 113-136).

7 This book is based on Khalil's doctoral dissertation entitled Muslim Scholarly Discussion on Salvation and the Fate of 'Others' (2007).

8 For an English translation and commentary on this work, see Jackson (2002). The original Arabic work can be retrieved at http://www.ghazali.org/works/faysal-ar.pdf

9 For a helpful overview of this work, see Hoover. Retrieved from http://dx.doi.org.ezproxy. lib.monash.edu.au/10.1163/1877-8054_CMR COM 25572

${ }^{10}$ In addition to exclusivism, inclusivism and pluralism in the Jewish traditions, Brill also adds 'universalism'. This section will only focus on Brill's account of Jewish inclusivism.

${ }^{11}$ For historical takes on Jewish-Gentile relations, see Katz (1961). For modern Jewish responses to Christianity, see Jacob (1974).

${ }^{12}$ Interestingly, non-monotheistic religions such as Hinduism and Buddhism are missing from Brill's discussion of rabbinical inclusivism. For his later work that deals with Hinduism and Buddhism, see Brill (2012); for an anthology of Jewish theology of religions, see Goshen-Gottstein \& Korn (2012); for individual works on Jewish theology of Hinduism, see Goshen-Gottstein (2016a and 2016b).

${ }^{13}$ It is puzzling why Brill does not include Reform Jewish Rabbi Kaufmann Kohler (18431926) as an inclusivist of the first type because it seems clear to me that Kohler does share a similar view concerning the 'historical mission' of Christianity and Islam in bringing humanity closer to monotheism. Consider: 
Though they have incorporated many non-Jewish elements in their systems, [Christianity and Islam] have spread the fundamental truths of the Jewish faiths and Jewish ethics to every part of the earth. Christianity in the West and Islam in the East have aided in leading mankind ever nearer to the pure monotheistic truth. Consciously or unconsciously, both found their guiding motive in the Messianic hope of the prophets of Israel and based their moral systems on the ethics of the Hebrew Scriptures. The leading spirits of Judaism recognized this, declaring both the Christian and Mohammedan religions to be agencies of Divine Providence, intrusted with the historical mission of cooperating in the building up of the Messianic Kingdom, thus preparing for the ultimate triumph of pure monotheism in the hearts and lives of all men and nations of the world (1918, p. 426).

Retrieved from https://www.questia.com/read/1684326/jewish-theology-systematicallyand-historically-considered

${ }^{14}$ It is often noted in the literature that non-Jews can earn salvation in the world to come, provided that they observe seven Noahide laws concerning adjudication (denim), illegitimate sex (giluy arayot), murder (shefikhut damim), theft (ha-gezel), blasphemy (qilelat Ha-Shem), false idolatry (avodah zarah), and improper dietary (ever min ha-hy). For a classic study of the seven laws of Noah, see Novak (2011).

${ }^{15}$ For more accounts of the diversity within Hinduism, see Lipner (2010) and Sharma (2011, pp. 309-320).

${ }^{16}$ A similar point is also made by Lott (1980, p. 22).

${ }^{17}$ For a brief but useful introduction to liberation according to different schools of Hinduism, see Bhaskarananda (2002, pp. 179-184). See also Sribhashyam and Sheshadri (2011, pp. 41-80).

${ }^{18}$ See also Torswesten (1991).

${ }^{19}$ Clooney is, perhaps, the only one in the literature who has seriously attempted to make sense of the plurality of Hindu views of other religions: "[O]ne might describe [the Hindu views of others] as tending respectively toward (1) exclusivism (Kumarila); Inclusivism (Ramanuja); (3) pragmatic interreligious collaboration in search of truth and non-violence (Gandhi); (4) hierarchical inclusivism (Vivekananda); and (5) oppositional inclusivism (Swarup)" (2003, p. 308) $\rightarrow$ Clooney (2003) is not in the reference. Unfortunately, Clooney does not include Radhakrishnan in this typology of Hindu views of non-Hindu religions. For a useful discussion of the Hindu encounter with Buddhism, Christianity and Islam, see Klostermaier (2007, pp. 369-409).

${ }^{20}$ A similar hierarchical thinking is also evident in the writings of Iyer $(1999 \rightarrow$ Not in the reference, p. 9) and Bhaskarananda (2009, pp. 133-140) on Advaita Vedanta.

${ }^{21}$ It is interesting to note here that Netland (2001) also makes a similar point, although he does not argue that Radhakrishnan is a Hindu exclusivist. For example, Netland writes:

[T] he unity of religions Radhakrishnan advocated was based upon what he perceived as the inner core of all true religions, the kind of mysticism that finds its highest expression in Advaita Vedanta Hinduism. While Advaita Vedantins acknowledge a personal deity, they see this deity as really but one aspect of the Absolute, nirguna Brahman, which transcend all duality, and accommodate the teachings and founding figures of other religions within a 
Vedantin framework as lesser approximations of what is most fully available in Advaita Vedanta. In other words, Radhakrishnan's acceptance of other religious traditions was strictly on the terms of his prior commitments to the epistemology and ontology of Vedanta Hinduism... Radhakrishnan, in other words, was not really a pluralist but rather a modern Hindu who understood religious diversity in terms of a modified Advaita Vedanta framework (2001, pp. 215-216).

${ }^{22}$ See Kiblinger (2005, pp. 33-38), Frieberger (2013, pp. 46-56), de Silva (2013, pp. 117-129), Hayes (2013, pp. 130-151) and Makransky (2013, pp. 173-198). For example, Kiblinger (2005) identified scriptural evidence for the Buddha's inclusivism: Mahaparinibana Sutta, Upali Sutta, Kalama Sutta and Samannaphala Sutta.

${ }^{23}$ For a non-exclusivist interpretation of this passage, see Dhammavisuddhi (2013) and Vélez de Cea (2013).

${ }^{24}$ See also Makransky (2013, pp. 178-179).

${ }^{25}$ For the most comprehensive anthology of Buddhism and religious diversity, see SchmidtLeukel, Ed. (2013). For helpful overviews of the Buddhist attitude towards other religions, see Kiblinger (2008, pp. 24-46), Burton (2011, pp. 321-336), and Chappel (2013, pp. 10-24).

${ }^{26}$ For other Buddhist inclusivists, see Hanh (1975, 1995, 1999); and Makransky (2008, pp. 47-68). For a detailed critique of Hanh's inclusivism, see Kiblinger (2005, pp. 91-102).

${ }^{27}$ For a useful anthology of the Jewish, Islamic, Buddhist and Hindu views of Jesus, see Baker (2008).

${ }^{28}$ For more developed accounts of Jesus as Bodhisattvas, see Brinkman (2009, pp. 80-100) and Keel (1996). For a Christian account of Jesus as an Enlightened One, see Phan (2004, pp. 130-136).

${ }^{29}$ See Abe (1985), (1995b), (1997) and (2003).

${ }^{30}$ Abe is not the only one who tries to locate the doctrine of Emptiness in Christianity. Keel's account of the parallels between Bodhisattva and Jesus Christ is also based on Buddhism's Emptiness and Christianity's Jesus. See Keel (1996).

${ }^{31}$ See also Abe (1997, pp. 54-66). For Christian responses to Abe's notion of kenotic God, see Cobb, Jr. and Ives (1990) and Ives (1995). See also Fredericks (2004, pp. 92-94). For a Christian model of the Empty Jesus, see O'Leary (1995, pp. 205-258).

${ }^{32}$ For a detailed critique of Kiblinger's version of Buddhist inclusivism, see Vélez de Cea (2013, pp. 113-116).

${ }^{33}$ I am indebted to Chadha (2015) for this piece of information.

\section{REFERENCES}

Abe, M. (1985). Zen and western thought. W. R. LaFleur (Ed.) Honolulu, HI: University of Hawaii Press.

Abe, M. (1995a). Kenotic God and dynamic Sunyata. In C. Ives (Ed.), Divine Emptiness And Historical Fullness: A Buddhist-Jewish-Christian Conversation with Masao Abe (pp. 25-90). Valley Forge, PA: Trinity Press International. 
Abe, M. (1995b). Buddhism and interfaith dialogue. S. Heine (Ed.). Honolulu, HI: University of Hawaii Press.

Abe, M. (1997). Zen and comparative studies. S. Heine (Ed.). Honolulu, HI: University of Hawaii Press.

Abe, M. (2003). Zen and the modern world. S. Heine (Ed.). Honolulu, HI: University of Hawaii Press.

Adiprasetya, J. (2013). An imaginative glimpse: The trinity and multiple religious participations. Eugene, OR: Pickwick Publications.

Al-Ghazali, A. H. M. Faysal al-Tafriqa bayn al-Islam was al-Zandaqa. Retrieved from http:/www.ghazali.org/works/faysal-ar.pdf

Atay, R. (2014). Religious pluralism and Islam: A critical reading of John Hick's pluralistic hypothesis. Saarbucken, Germany: Scholar Press.

Aydin, M. (2001). Religious pluralism: A challenge for Muslims-a theological evaluation. Journal of Ecumenical Studies, 38(2-3), 330-352. Retrieved from http://go.galegroup.com.ezproxy.lib.monash.edu.au/ps/i.o?p=AONE $\& \mathrm{sw}=\mathrm{w} \& \mathrm{u}=$ monash $\& \mathrm{v}=2.1 \& \mathrm{it}=\mathrm{r} \& \mathrm{id}=\mathrm{GALE} \% 7 \mathrm{CA} 98313413 \& \mathrm{asid}=51 \mathrm{f0}$ c297e1e62d6aa02a6fc51f14d443

Aydin, M. (2002). Reconciliation in Islamic theology. Journal of Ecumenical Studies, 39 (1-2), 141+. Retrieved from http://go.galegroup.com.ezproxy. lib.monash.edu.au/ps/i.do? $\mathrm{p}=\mathrm{AONE} \& \mathrm{sw}=\mathrm{w} \& \mathrm{u}=\mathrm{monash} \& \mathrm{v}=2.1 \& \mathrm{it}=\mathrm{r} \& \mathrm{i}$ $\mathrm{d}=\mathrm{GALE} \%$ 7CA112798585\&asid=73e689f067fa088bbb29062b5a9e93a3

Baker, G. A. (Ed.) (2008). Jesus in the world's faiths: Leading thinkers from five religions reflect on his meaning. Maryknoll, NY: Orbis Books.

Becker, K. J., \& Morali, I. (Eds.) (2010). Catholic engagement with world religions: A comprehensive study. Maryknoll, NY: Orbis Books.

Bhaskarananda, S. (2002). The essentials of Hinduism: A comprehensive overview of the world's oldest religion. Seattle, WA: Viveka Press.

Bhaskarananda, S. (2009). Journey from many to one: Essentials of Advaita Vedanta. Seattle, WA: Viveka Press.

Bradley, H. (2012). Flames of love: Hell and universal salvation. Eugene, OR: Wipf \& Stock Publishers.

Brill, A. (2010). Judaism and other religions. New York, NY: Palgrave Macmillan.

Brill, A. (2012). Judaism and world religions: Encountering Christianity, Islam and eastern traditions. New York, NY: Palgrave Macmillan.

Brinkman, M. E. (2009). The non-western Jesus: Jesus as Bodhisattva, Avatara, Guru, Prophet, Ancestor or Healer. New York, NY: Routledge.

Burton, D. (2011). A Buddhist perspective. In C. Meister, (Ed.), The Oxford handbook of religious Diversity (pp. 321-336). Oxford, United Kingdom: Oxford University Press.

Chadha, M. (2015). The Hindu models of divinity. In G. Oppy (Ed.). The Routledge Handbook of Contemporary Philosophy of Religion (pp. 127-137). Abingdon, United Kingdom: Routledge. 
Chappel, D. (2013). Six Buddhist attitudes towards other religions. In P. SchmidtLeukel (Ed.), Buddhism and Religious Diversity (Vol. VI, pp. 10-24). Abingdon, United Kingdom: Routledge.

Cheetham, D. (2013). Ways of meeting and the theology of religions. Abingdon, United Kingdom: Routledge.

Clooney, F. X. (2003). Hindu views of religious others: Implications for Christian theology. Theological studies, 64(2), 306-333.

Cobb, Jr., J. B. \& Ives, C. (Eds.). (1990). The emptying God: A Buddhist-JewishChristian conversation. Eugene, OR: Wipf and Stock Publishers.

Cohn-Sherbok, D. (1994) Judaism and other faiths. Basington, Hampshire, United Kingdom: The Macmillan Press.

D' Costa, G. (1986). Theology and religious pluralism: The challenge of other religion. Oxford, United Kingdom: Basil Blackwell.

D'Costa, G. (2000). The meeting of religions and the trinity. New York: Orbis Books.D'Costa, G. (2009). Christianity and world religions: Disputed questions in the theology of religion. West Sussex, United Kingdom: WileyBlackwell.

De Silva, L. (2013). The Buddha, the eightfold path and the other religions. In P. Schmidt-Leukel (Ed.), Buddhism and Religious Diversity (Vol. 4, pp. 117-129). Abingdon, United Kingdom: Routledge.

Dhammavisuddhi, Y. (2013). Does Buddhism recognize liberation from samsara outside its own dispensation? In P. Schmidt-Leukel (Ed.), Buddhism and Religious Diversity, (Vol. IV, pp. 109-116). Abingdon, United Kingdom: Routledge.

Dinoia, J. A. (1992). The diversity of religions. Washington, D.C: The Catholic University of America Press.

Dupuis, J. (1997). Toward a Christian theology of pluralism. Maryknoll, NY: Orbis Books.

Fredericks, J. L. (2004). Buddhist and Christians: Through comparative theology to solidarity. Maryknoll, New York: Orbis Books.

Freiberger, O. (2013). How the Buddha dealt with non-Buddhists. In P. SchmidtLeukel (Ed.), Buddhism and Religious Diversity (Vol. 4, pp. 46-56). Abingdon, United Kingdom: Routledge.

Goshen-Gottstein, A. \& Korn, E. (Eds.). (2012). Jewish theology and world religions. Portland, OR: The Littman Library of Jewish Civilization.

Goshen-Gottstein, A. (2016a). Same God, other God: Judaism, Hinduism, and the problem of idolatry. Basington, United Kingdom: Palgrave Macmillan.

Goshen-Gottstein, A. (2016b). The Jewish encounter with Hinduism: Wisdom, spirituality, identity. Basington, United Kingdom: Palgrave Macmillan.

Greggs, T. (2009). Barth, Origen, and universal salvation. Oxford, United Kingdom: Oxford University Press. 
Hanh, T. N. (1975). The raft is not the shore: Conversations toward a BuddhistChristian awareness. Maryknoll, NY: Orbis Books.

Hanh, T. N. (1995). Living Buddha, living Christ. New York, NY: Riverhead Books.

Hanh, T. N. (1999). Going home: Jesus and Buddha as brothers. New York, NY: Riverhead Books.

Harris, E., Hedges, P., \& Hettiarachchi, S. (2016). Twenty-first century theologies of religions. Leiden, The Netherlands: Koninklijke Brill NV.

Hayes, R. P. (2013). Gotama Buddha and religious pluralism. In P. Schmidt-Leukel (Ed.), Buddhism and Religious Diversity (Vol. 4, pp. 130-151). Abingdon, United Kingdom: Routledge.

Hedges, P. \& Race, A. (Eds.). (2008). Christian approaches to other faiths. London, United Kingdom: SCM Press.

Hedges, P. (2008). A reflection on typologies: Negotiating a fast-moving discussion. In P. Hedges \& A. Race (Eds.), Christian Approaches to Other Faiths (pp. 23-26). London: SCM Press.

Heim, S. M. (2001). The depths of the riches: A trinitarian theology of religious ends. Grand Rapids, MN: WM. B. Eerdmans Publishing Co.

Hick, J. (2001). Dialogues in the philosophy of religion. Hampshire, United Kingdom: Palgrave.

Hoover, J. Al-jawāb al-ṣaḥịh li-man baddala dīn al-Masīḥ. In D. Thomas (Ed.) Christian-Muslim Relations 600 - 1500. Retrieved from http://dx.doi.org. ezproxy.lib.monash.edu.au/10.1163/1877-8054_CMR_COM_25572>

Ives, C. (1995). Divine emptiness and historical fullness: $\bar{A}$ Buddhist-JewishChristian conversation with Masao Abe. Valley Forge, PA: Trinity Press International.

Iyer, V. S. (1999). Advaita: The truth of non-duality (from the posthumous collections of P. Brunton). M Scorelle (Ed.). Rhinebeck, NY: Epigraph Books.

Jackson, S. A. (2002). On the boundaries of theological tolerance in Islam: Abu Hamid al-Ghazali's Faysal al Tafriqa. Oxford: Oxford University Press.

Jacob, W. (1974). Christianity through Jewish eyes: The quest for common ground. USA: The Hebrew Union College Press.

Jayatilleke, K. N. (2013). The Buddhist attitude to other religions'. In P. SchmidtLeukel (Ed.), Buddhism and religious diversity (Vol. 4, pp. 88-108). Abindon, United Kingdom: Routledge.

Jersak, B. (2009). Her gates will never be shut: Hope, hell and the New Jerusalem. Eugene: Wipf and Stock Publishers.

Johnson, K. E. (2011). Rethinking the trinity \& religious pluralism: An Augustinian assessment. Downers Gove, IL: IVP Academics.

Kamali, M. H. (2011). Islam's religious pluralism in context. Islam and Civilisational Renewal, 2(4), 714-716. Retrieved from http://search.proquest.com/docvie w/1315158993? accountid=12528 
Kärkkäìnen, V. (2003). An introduction to the theology of religions: Biblical, historical and contemporary perspectives. Downers Grove, IL: InterVarsity Press.

Kärkkäìnen, V. (2013). Christ and reconciliation: A constructive Christian theology for the pluralistic world, Vol. 1. Grand Rapids, MI: Wm. B. Eerdmans Publishing Co.

Kärkkäìnen, V. (2014). Trinity and revelation: A constructive Christian theology for the pluralistic world, Vol. 2. Grand Rapids, MI: Wm. B. Eerdmans Publishing Co.

Kärkkäìnen, V. (2015). Creation and humanity: A constructive Christian theology for the pluralistic world, Vol. 3. Grand Rapids, MI: Wm. B. Eerdmans Publishing Co.

Kärkkäìnen, V. (2016). Spirit and salvation: A constructive Christian theology for the pluralistic world, Vol. 4. Grand Rapids, MI: Wm. B. Eerdmans Publishing Co.

Katz, J. (1961). Exclusiveness and tolerance: Studies in Jewish-Gentile relations in medieval and modern times. Springfield, NJ: Behrman House, Inc.

Keel, H. S. (1996). Jesus the Bodhisattva: Christology from a Buddhist perspective. Buddhist-Christian Studies, 16, 169-185.

Khalil, M. H. (2007). Muslim scholarly discussions on salvation and the fate of 'Others'(Order No. 3276201). Available from ProQuest Dissertations \& Theses Global. (304847949). Retrieved from http://search.proquest.com/ docview/304847949? accountid $=12528$

Khalil, M. H. (2012). Islam and the fate of others. Oxford, United Kingdom: Oxford University Press.

Khalil, M. H. (2013). Between heaven and hell: Islam, salvation and the fate of others. Oxford, United Kingdom: Oxford University Press.

Khodr, G. (1971). Christianity in a pluralistic world: The economy of the holy spirit. The Ecumenical Review, 23(2), 118-128.

Kilbinger, K. B. (2005). Buddhist inclusivism: Attitudes towards religious others. Hants, United Kingdom: Ashgate Publishing Limited.

Klostermaier, Klaus K. (2007). A survey of Hinduism. Albany, NY: State University of New York Press.

Knitter, P. E. (1985). No other names? A critical survey of Christian attitudes toward the world religions. Maryknoll, NY: Orbis Books.

Knitter, P. E. (2002). Theologies of religions. Maryknoll, NY: Orbis Books.

Kohler, K. (1918). Jewish theology: Systematically and historically considered. New York, NY: Macmillan Retrieved from https://www.questia.com/ $\mathrm{read} / 1684327 /$ jewish-theology-systematically-and-historically-considered

Kronen, J. \& Reitan, E. (2011). God's final victory: A comparative philosophical case for universalism. New York, NY: Bloomsbury Academic. 
Lawrence, D. P. (2013). Hindu theism. In V. Lawrence, C. Taliaferro \& S. Goetz (Eds.), The Routledge companion to theism (pp. 77-87). Abingdon, United Kingdom: Routledge.

Lipner, J. (2010). Hindus: Their religious beliefs and practices (2nd ed.). Abingdon, United Kingdom: Routledge.

Lott, E. J. (1980). Vedantic approaches to God. London, United Kingdom: Palgrave Macmillan.

MacDonald, G. (2011). All shall be well: Explorations in universal salvation and Christian theology, from Origen to Moltmann. Eugene, OR: Wipf and Stock Publishers.

MacDonald, G. (2012). The evangelical universalist. (2nd ed.). Eugene, OR: Cascade Books.

Makransky, J. (2008). Buddhist inclusivism: Reflections toward a contemporary Buddhist theology of religions. In P. Schmidt-Leukel, Ed. Buddhist Attitudes to Other Religions, (pp. 47-68). Germany: EOS Editions of St. Ottilien.

Makransky, J. (2013). Buddhist perspectives on truth in other religions: Past and present. In P. Schmidt-Leukel (Ed.) Buddhism and Religious Diversity (Vol. 4, pp. 173-198). Abingdon, United Kingdom: Routledge.

Markham, I. (1993), Creating options: Shattering the 'exclusivist, inclusivist, and pluralist' paradigm. New Blackfriars, 74, 33-41. http://dx.doi. org/10.1111/j.1741-2005.1993.tb07288.x

Markham, I. (2004). Christianity and other religions. In G. Jones (Ed.), The Blackwell companion to modern theology (pp. 405-417). Oxford, United Kingdom: Blackwell Publishing Ltd.

McDermont, G. R. (2007) God's rivals: Why has God allowed different religions? Insights from the Bible and the early Church. Downers Grove, IL: IVP Academics.

Moltmann, J. (1993). Theology of hope: On the ground and the implications of a Christian eschatology. Minneapolis, MN: Augsburg Fortress Publishers.

Muck, T. (2002). Instrumentality, complexity, and reason: A Christian approach to religions. Buddhist-Christian Studies, 22, 115-121. Retrieved from http:// www.jstor.org.ezproxy.lib.monash.edu.au/stable/1390569

Nah, D. S. (2012). Christian theology and religious pluralism: A critical evaluation of John Hick. Eugene, OR: Pickwick Publications.

Netland, H. (2001). Encountering religious pluralism: The challenge to Christian faith \& mission. Downers Grove, IL: IVP Academic.

Netland, H. (2008). Religious exclusivism. In P. Copan \& C. V. Meister (Eds.), Philosophy of religion: Classic and contemporary Issues (pp. 67-80). Oxford, United Kingdom: Blackwell.

Novak, D. (2011). The image of the non-Jew in Judaism. (2nd ed.). Mathew Lagrone, (Ed.) Portland, Oregon: The Littman Library of Jewish Civilization. 
O’Collins, G. (2008). Salvation for all: God's other peoples. Oxford, United Kingdom: Oxford University Press.

O’Leary, J. S. (1995). Religious pluralism and Christian truth. Eugene, OR: Wipf and Stock Publishers.

Pannenberg, W. (1991). Systematic theology (Vol. I). (G. Bomiley, Trans). Grand Rapids, Mi: Eardmans.

Panikkar, R. (2009). The Trinity and the religious experience of man: Icon-PersonMystery. Maryknoll, NY: Orbis Books,

Phan, P. C. (2004). Being religious interreligiously: An Asian perspective on interfaith dialogue. Maryknoll, NY: Orbis Books.

Pinnock, C. H. (1992). A wideness in God's mercy: The finality of Jesus Christ in a world of religions. Grand Rapids, MI: Zondervan Publishing House.

Pinnock, C. H. (1996). Flame of love: A theology of Holy Spirit. Downers Grove, IL: IVP.

Polish, D. (1990). Attitudes of Judaism toward non-Jews. In L. Swidler \& P. Mojzes, (Eds.). Attitudes of Religions and Ideologies Toward the Outsider: The Other (pp. 47-62). London, United Kingdom: The Edwin Mellen Press.

Punt, N. (2008). A theology of inclusivism. Allendale, MI: Northland Books.

Race, A. (1983). Christians and religious pluralism. Maryknoll, NY: Orbis Books.

Radhakrishnan, S. (1940). Eastern religions and western thought (2nd ed.). Amen House, London, United Kingdom: Oxford University Press.

Radhakrishnan, S. (1957). An idealist view of life (2nd ed.). London, United Kingdom: George Allen and Unwin Ltd.

Radhakrishnan, S. (1960). The Hindu view of life. London, United Kingdom: Unwin Books.

Rahman, F. (2013). The people of the book and diversity of religions. In L. Ridgeon (Ed.), Islam and Religious Diversity (Vol. 4, pp. 1-8) Abingdon, United Kingdom: Routledge.

Rahner, K. (2008). Christianity and the non-Christian religions. In M. Palmer (Ed.), The Philosopher of Religion: Classic and Contemporary Readings (pp. 553-556). Cambridge, United Kingdom: Fortress Press.

Ridgeon, L. (Ed.). (2012). Islam and religious diversity. (Vols. 1-4). Oxford, United Kingdom: Routledge.

Sabjan, M. A. (2009). The people of the book and the people of a dubious book in Islamic religious tradition. Pulau Pinang, Malaysia: Penerbit Universiti Sains Malaysia.

Sachedina, A. (1986). Jews, Christians, and Muslims according to the Qu'ran. Greek Orthodox Theological Review, 31(1-2), 105-120.

Sachedina, A. (2006). The Qur'ān and other religions. In J. D. McAuliffe (Ed.), The Cambridge companion to the Qur'an, (pp. 291-309). Cambridge, United Kingdom: Cambridge University Press. http://dx.doi.org/10.1017/ CCOL0521831601.015 
Sanders, J. (1992). No other name: An investigation into the destiny of the unevangelized. Eugene, OR: Wipf and Stock Publishers.

Schmidt-Leukel, P. (2005). Exclusivism, inclusivism, pluralism: Tripolar-clarified and reaffirmed. In P. F. Knitter (Ed.). The myth of religious superiority (pp. 13-22). Maryknoll, NY: Orbis Books.

Schmidt-Leukel, P. (Ed). (2013). Buddhism and religious diversity. (Vols. 1-4). Oxford, United Kingdom: Routledge.

Shah-Kazemi, R. (2010). Common ground between Islam and Buddhism. Louisville, KY: Fons Vitae.

Sharma, A. (2011). A Hindu perspective. In C. Meister, (Ed.), The Oxford Handbook of Religious Diversity, (pp. 309-320). Oxford, United Kingdom: Oxford University Press.

Shatz, D. (2011). A Jewish Perspective. In C. Meister, (Ed.), The Oxford Handbook of Religious Diversity, (pp. 372-373). Oxford, United Kingdom: Oxford University Press.

Sribhashyam, T. K. \& Sheshadri, A. (2011). Way to liberation Moksa-Mãrga: An itinerary to Indian philosophy. New Delhi, India: D. K. Printworld (P) Ltd.

Strange, D. (2002). The possibility of salvation among theuunevangelised: An analysis of inclusivism in recent evangelical theology. Eugene, OR: Wipf and Stock Publishers.

Talbott, T. (2014). The inescapable love of God. (2nd ed.). Eugene, OR: Wipf and Stock Publishers.

The Dalai Lama. (1996). The good heart: A Buddhist perspective on the teaching of Jesus. Simerville, MA: Wisdom Publication.

Tiessen, T. L. (2004). Who can be saved? Reassessing salvation in Christ and world religions. Downers Grove, IL: IVP.

Torwesten, H. (1991). Vedanta: Heart of Hinduism. New York, NY: Grove Press. Vélez de Cea, J. A. (2011). A cross-cultural and Buddhist-friendly interpretation of the typology exclusivism-inclusivism-pluralism. Sophia. 50 (3), 453-480. http://dx.doi.org/10.1007/s11841-011-0242-8

Vélez de Cea, J. A. (2013). The Buddha and religious diversity. Oxford, United Kingdom: Routledge.

Waardenburg, J., (Ed.). (1999). Muslim perceptions of other religions: A historical survey. Oxford, United Kingdom: Oxford University Press.

Waardenburg, J. (2003). Muslims and others (religion and reason). Berlin, Germany: Walter de Gruyter GmbH \& Co.

Ward, K. (2012). Pluralism revisited. In S. Sugirtharajah (Ed.). Religious pluralism and the modern world: An ongoing engagement with John Hick. (pp. 58-67). Hampshire, United Kingdom: Palgrave Macmillan.

Yong, A. (2003). Beyond the impasse: Toward a pneumatological theology of religions. Eugene, OR: Wipf and Stock Publishers. 
Yong, A. (2005). The spirit poured out on all flesh: Pentecostalism and the possibility of global theology. Grand Rapids, MI: Baker Academic.Yusuf, S. H. (2010). Buddha in Qur'an? In R. Shah Kazemi, Common ground between Islam and Buddhism (pp. 113-236). Louisville, KY: Fons Vitae.

Zia-Ul-Haq, M. (2010). Religious diversity: An Islamic perspective. Islamic Studies. 49 (4), 493-519. Retrieved from http://www.jstor.org.ezproxy.lib.monash. edu.au/stable/41581121 